10 years ESJ

Special edition

\title{
The Impact of Covid-19 Pandemic on The Work Landscape and Employment Policy Responses: Insights From Labor Policies Adopted in The Greek Context
}

\author{
Eleni Triantafillidou, PhD candidate \\ Democritus University of Thrace, Greece \\ Theodore Koutroukis, Associate Professor \\ Democritus University of Thrace, Greece and Neapolis University of Pafos \\ Doi: 10.19044/esj.2021.v17n31p179 \\ Submitted: 12 May 2021 \\ Accepted: 05 July 2021 \\ Published: 15 September 2021 \\ Copyright 2021 Author(s) \\ Under Creative Commons BY-NC-ND \\ 4.0 OPEN ACCESS \\ Academic Editors: Georgios Farantos \& Nikitas-Spiros Koutsoukis \\ Cite As: \\ Triantafillidou E \& Koutroukis T. (2021). The Impact of Covid-19 Pandemic on The Work \\ Landscape and Employment Policy Responses: Insights From Labor Policies Adopted in The \\ Greek Context. European Scientific Journal, ESJ, 17 (31), 179. \\ https://doi.org/10.19044/esj.2021.v17n31p179
}

\section{Abstract}

This study explores the impact of Covid-19 on labor relations and public labor relations policies. Focus is given to the worldwide effects of the pandemic on employment, the impact of Covid-19 on the European labor landscape, the impact of the pandemic on the Greek labor context, and the main labor policies and measures adopted in Greece during Covid-19. The analysis of the effects of the pandemic on employment is based on published research material from ILO, Eurofound and the database of the Greek Ministry of Labor. The section concerning the impact of Covid-19 on the labor relations policies and the measures adopted in the Greek context is based on the analysis of the Greek institutional framework and the related legislative acts. The main employment policy responses to Covid-19 pandemic are ensuring workers' safety, maintaining adequate paid sick leave, upholding support for workers with caring needs, adapting job retention schemes, ensuring adequate income protection, expanding employment services and training and giving the young people the support they need. Planning and implementing effective labor policies is a demanding goal that requires cooperation and synergies among 
economic, research, innovation and lifelong education policies.

Keywords: Covid-19, Labor Relations, Labor Market, Public Policies

\section{Introduction}

The coronavirus crisis caused unprecedented consequences for the global economy (Vlados, 2020a). Quarantine measures, lockdowns, and restrictions imposed to control the rate of transmission of the Covid-19 affected most economic activities and particularly those that involve physical interactions. The Covid-19 pandemic disrupted global supply chains, international trade, transportation services, tourism and hospitality due to restrictions and closures in the international borders (Vlados, 2020b). Service sectors as retail, travel, leisure, restaurants and personal services that require direct contact between the consumer and the provider of the service are severely affected due to social distancing restrictions (Chatzinikolaou et al., 2021). The Covid-19 pandemic impact on employment has short-term, medium term and long-term effects as job losses, reduction in productivity, income inequality, social inequalities for vulnerable workers as minorities, older employees, young people and women (Brodeur et al., 2020). Some of the categories of working-hour losses are fewer average weekly working hours, employees typically employed but not actually working, rise in unemployment, and inactivity as removal from the labor force (Fana et al., 2020). In Greece there is a rising trend in unemployment, reduction of working hours, undeclared work and flexible forms of labor provision (Hazakis, 2021). Covid-19 pandemic created economic, health and social crises, and challenges. Companies and organizations of private and public sectors have adopted teleworking, flexible forms of employment, remote services and digital transformations. Strict lockdowns and restriction measures raise issues and conversations concerning the balance between public health, human rights and entrepreneurial freedom.

\section{Methods and research material used}

The main research method used is the review of the literature on the impact of Covid-19 pandemic on the employment and labor relation policies. The analysis of the effects of the pandemic on employment is based on published research material and evaluation of data from ILO, Eurofound and the database of the Greek Ministry of Labor. We analyze secondary data from the Information System of the Hellenic Ministry of Labour and Social Security to identify how Covid-19 pandemic crises affected the number of recruitments and the employment forms. The section concerning the impact of Covid-19 on labor relations policies and the measures adopted in the Greek context is based 
on the analysis of the Greek institutional framework and the related legislative acts.

\section{Impact of Covid-19 on the work landscape}

\subsection{Worldwide effects of pandemic on the employment}

According to ILO report (2021), the pandemic crisis has affected and continues to affect, directly or indirectly, more than $75 \%$ of the global workforce as most workers live in countries with lockdowns or workplace closures for some sectors or categories of employees. More than $40 \%$ of the potential workforce is at risk of falling into long-term unemployment. There is a drastic reduction in working hours of more than $8.8 \%$ worldwide which is equivalent to 225 million full-time jobs. America, Europe and Central Asia will experience the greatest loss in working hours.

The decline in working hours or working-hour losses, worldwide in 2020, is composed of two dimensions: (1) employment losses and (2) reduction in working hours for employees who remained employed. Employees who are at a loss of employment are either "unemployed" which means they are active and search for new jobs or "inactive" which means that they remove from the labor market as they are not willing to work and/or they do not search for a job. The highest employment losses were in America and the lowest in Europe and Central Asia as in Europe schemes for job retention supported the reduction in working hours. The total global employment losses in 2020 were 114 million jobs. Employment losses were higher for women and young workers than men and older workers. Moreover, in 2020 the employment losses translated into a shift to inactivity rather than a shift to unemployment. $71 \%$ ( 81 million out of 114 million) of global employment losses corresponds to a shift to inactivity and 28.9\% (33 million out of 114 million) corresponds to a shift to unemployment. In 2020, global unemployment increased 33 million with the unemployment rate rising by $1.1 \%$ to $6.5 \%$.

Figure 1. Estimation of the working hours and employment lost in 2020

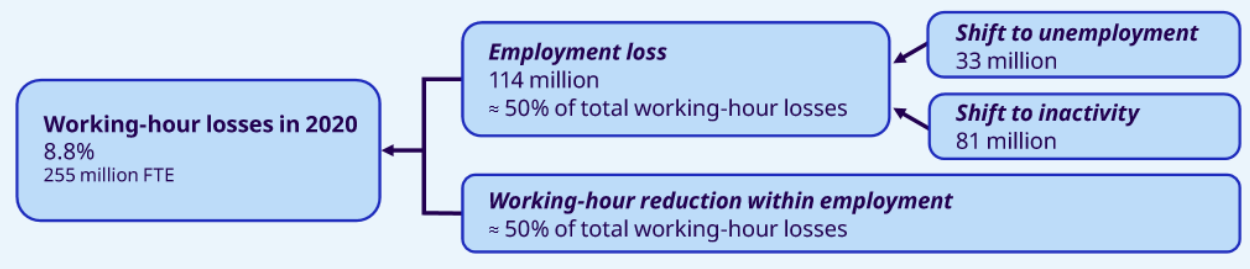

Source: ILO, 2021

\subsection{Impact of Covid-19 on the European labor landscape}

According to Eurofound (2020), 10\% of workers left the workforce and $8 \%$ became unemployed, young women and self-employed respondents 
were most likely to lose their job, over a third of employees had their working hours reduced, women struggle with work-life balance more than men, particularly if they have young children, young employees experience more loneliness, tension and depression, more than one in three employees worked solely from home in July 2020, nearly half of young teleworkers had never worked from home before, solo self-employed at higher risk of becoming unemployed during the crisis, job insecurity significantly higher among the self-employed and one in five working as an employee has received financial support.

Covid-19 and measures of confinement affect employees, labor force and economic activities. The impact of Covid-19 in economic sectors is classified into five categories: (1) essential and fully active sectors. This category includes food production, health and other sectors in which unemployment continues to operate normally; (2) active but via telework. In this category public administration, education, finance, scientific and professional activities, insurance and telecommunications are included; 3) mostly essential and partly active, not teleworkable. This category includes a considerable part of the manufacturing and retail sector; (4) mostly nonessential and inactive, not teleworkable. In this category construction, machine repairs and the major part of manufacturing are included; (5) closed. This category cannot function via telework and includes restaurants, hotels, travel agencies and services for leisure and recreation. (European Commission Technical Report, 2020). The following chart presents the percentage of employees becoming unemployed in the EU countries since the onset of the pandemic.

Figure 2. Employees who became unemployed since the onset of the pandemic, by country $(\%)$

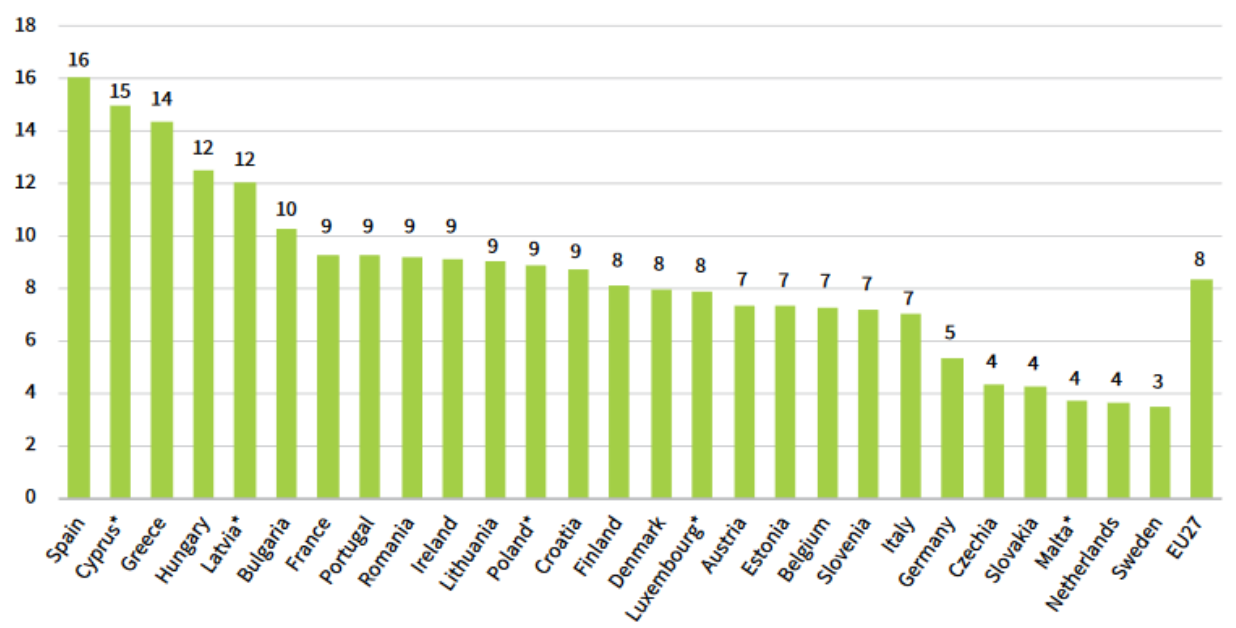

Source: Eurofound, 2020 

countries.

The next chart depicts the change (\%) in working hours in the EU

Figure 3. Change in working hours, by country (\%), July 2020

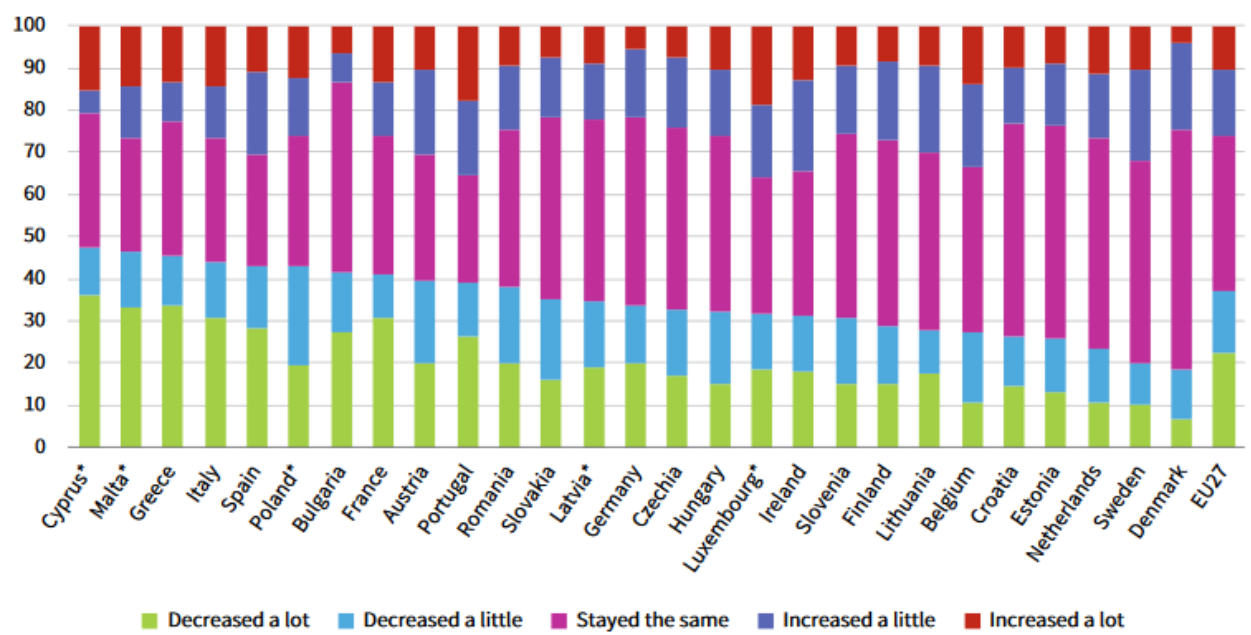

Source: Eurofound, 2020

\subsection{General impact of pandemic in the Greek labor context}

According to the Information System of the Greek Ministry of Labor "Ergani", there is a large drop in the number of new recruitments. More specifically total recruitments in 2018 are 2.668 .923 whereas in 2019 are 2.830 .885 (increase 161.962 or $6,07 \%$ ) and in 2020 are 1.986 .442 (decrease 844.443 or $-29,83 \%)$

Table 1. Recruitments in Greece 2018-2019-2020

\begin{tabular}{|c|c|c|c|c|c|c|}
\hline Period & $\begin{array}{l}\text { December } \\
\mathbf{2 0 2 0}\end{array}$ & $\begin{array}{c}\text { December } \\
\mathbf{2 0 1 9}\end{array}$ & $\begin{array}{c}\text { December } \\
\mathbf{2 0 1 8}\end{array}$ & $\begin{array}{c}\text { January - } \\
\text { December } \\
\mathbf{2 0 2 0}\end{array}$ & $\begin{array}{c}\text { January - } \\
\text { December } \\
\mathbf{2 0 1 9}\end{array}$ & $\begin{array}{c}\text { January - } \\
\text { December } \\
\mathbf{2 0 1 8}\end{array}$ \\
\hline Recruitments & 93.370 & 200.243 & 184.941 & 1.986 .442 & 2.830 .885 & 2.668 .923 \\
\hline
\end{tabular}

Source: Own compilation from Ergani, December 2019 \& December 2020

The following graph depicts the significant decrease taken into consideration the recruitments of the months December 2020 and December 2019. 
Graph 1. Comparative illustration of recruitments in Greece (December 2019 and December 2020)

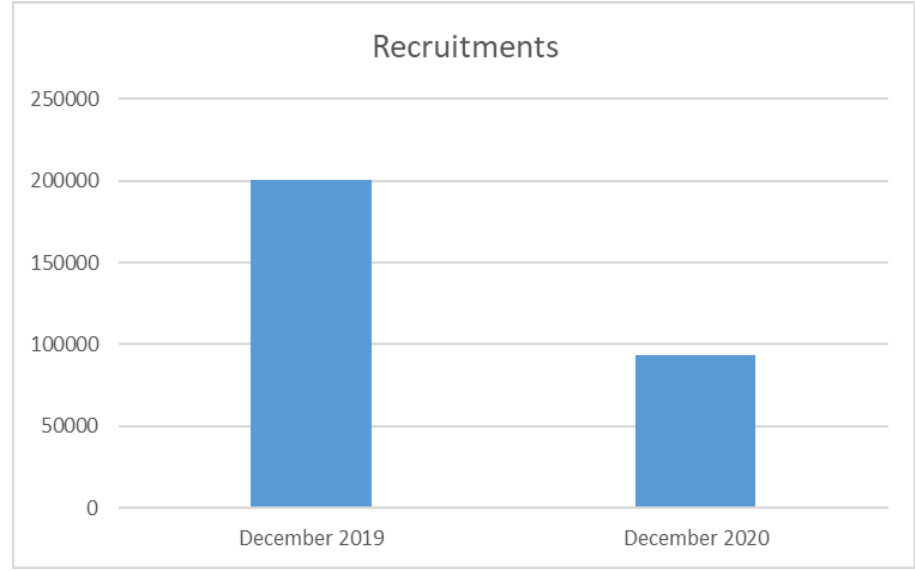

Source: Data processing survey

The following graph compares the total recruitments in Greece in 2018,2019 and 2020. In 2019 the total recruitments increased by 6,07\% compared to the total recruitments of 2018. On the contrary, in 2020 due to the pandemic the total recruitments decreased by $29,83 \%$ compared to the total recruitments of 2019.

Graph 2. Comparative illustration of recruitments in Greece $(2018,2019,2020)$

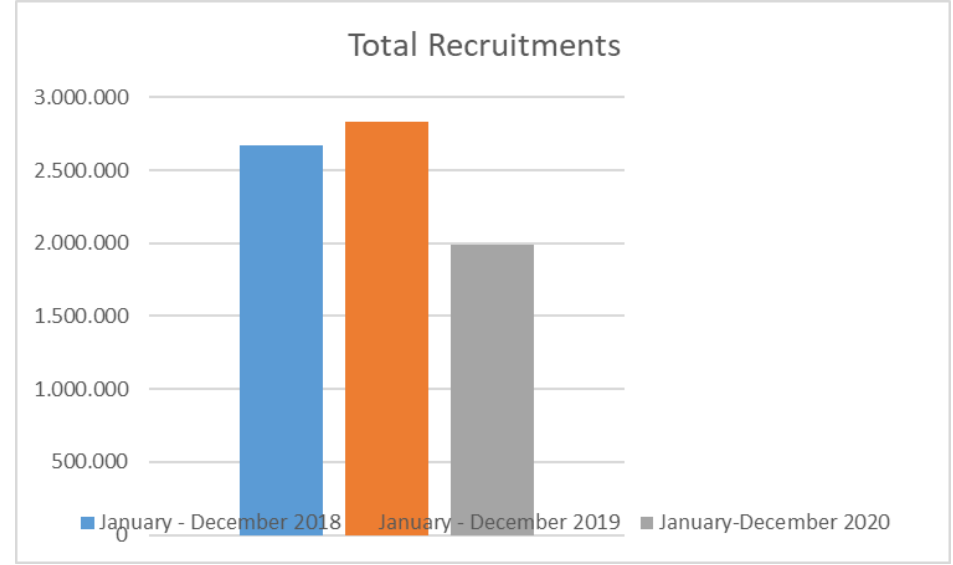

Source: Data processing survey

The next graph compares total recruitments per month in Greece in 2019 and 2020. The first two months of 2020 before the coronavirus crisis the total recruitments begun to increase compared to 2019. The launch of Covid19 in Greece in March 2020 caused a rapid decrease in the total recruitments. This image changed marginally and only for the summer period of 2020. 
Graph 3: Total recruitments in Greece - Comparison 2019 to 2020

Total recruitments comparison per month 2019 to 2020

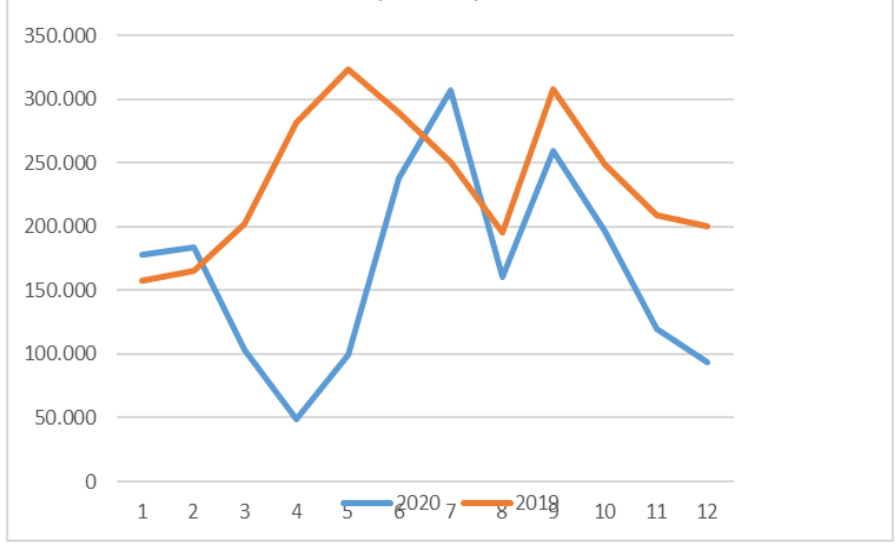

Source: Data processing survey

According to the Information System of the Greek Ministry of Labor "Ergani", about $45 \%$ of the employees in the private sector joined the status of suspension of the employment contract, receiving the relevant special purpose compensation. Also, an increase in the conversion of full-time employment contracts to shiftwork/job rotation is already beginning to emerge, suggesting a significant reduction in working hours in the private sector as a first reaction to the crisis. The following table compares the forms of employments as full time recruitments, part time recruitments and shiftwork/job rotation in 2019 and in 2020. 
Table 2. Forms of employment in Greece, 2019 \& 2020

\begin{tabular}{|c|c|c|c|c|c|c|c|c|}
\hline Month & $\begin{array}{l}\text { Full time } \\
\text { recruit- } \\
\text { ments } 2019 \\
\text { A1 }\end{array}$ & $\begin{array}{l}\text { Full time } \\
\text { recruit- } \\
\text { ments } 2020 \\
\text { A2 }\end{array}$ & $\begin{array}{l}\text { Part time } \\
\text { recruit- } \\
\text { ments } \\
2019 \\
\text { B1 }\end{array}$ & $\begin{array}{l}\text { Part time } \\
\text { recruit- } \\
\text { ments } \\
2020 \\
\text { B2 }\end{array}$ & $\begin{array}{l}\text { Shiftwork/J } \\
\text { ob rotation } \\
2019 \\
\text { C1 }\end{array}$ & $\begin{array}{l}\text { Shiftwork/J } \\
\text { ob rotation } \\
2020 \\
\text { C2 }\end{array}$ & $\begin{array}{l}\text { Total } 2019 \\
\text { A1+B1+C3 }\end{array}$ & $\begin{array}{l}\text { Total } 2020 \\
\mathrm{~A} 2+\mathrm{B} 2+\mathrm{C} 3\end{array}$ \\
\hline January & 73.485 & 82.382 & 65.113 & 74.392 & 18.543 & 20.858 & 157.141 & 177.632 \\
\hline February & 75.200 & 80.458 & 68.283 & 78.111 & 21.627 & 25.033 & 165.110 & 183.602 \\
\hline March & 92.740 & 57.732 & 82.170 & 37.883 & 27.247 & 7.387 & 202.157 & 103.002 \\
\hline Mai & 161.247 & 55.044 & 126.811 & 36.631 & 35.466 & 7.582 & 323.524 & 99.257 \\
\hline June & 125.618 & 118.786 & 128.317 & 96.934 & 35.554 & 22.633 & 289.489 & 238.353 \\
\hline July & 111.579 & 158.529 & 106.341 & 120.065 & 32.399 & 28.214 & 250.319 & 306.808 \\
\hline August & 87.208 & 82.267 & 82.367 & 65.680 & 28.850 & 12.636 & 195.425 & 160.583 \\
\hline September & 128.616 & 128.658 & 145.269 & 115.348 & 34.236 & 15.415 & 308.121 & 259.421 \\
\hline October & 92.536 & 92.982 & 122.455 & 88.404 & 33.601 & 14.898 & 248.592 & 196.284 \\
\hline November & 88.485 & 70.470 & 93.089 & 42.802 & 27.009 & 6.303 & 208.583 & 119.575 \\
\hline December & 85.669 & 63.033 & 86.342 & 25.945 & 28.232 & 4.389 & 200.243 & 93.370 \\
\hline Total & 1.277 .393 & 1.022 .789 & 1.203 .794 & 796.342 & 349.695 & 167.311 & 2.830 .885 & 1.986 .442 \\
\hline
\end{tabular}

Source: Own compilation from Ergani, December 2020 \& December 2019 
In Greece the centralized and funded by the European Union employment policy is passive rather than active and faces increased bureaucracy, administrative intersections and pitfalls of dispersal leading to policy ineffectiveness. (Maris, 2021; Plimakis et. al, 2021). According to Spyridakis (2020), the Covid-19 pandemic affects employees' adaptability to the transformations of work, workers social identity and the determinants of social solidarity in the Greek society. The Greek government should support in the short and medium-term value-added economic activities, private and public investments and labor income in order to avoid serious degradation of unemployment and poverty (Hazakis, 2021).

\section{Active Labor Policies}

\subsection{Active labor policies in EU countries}

Historically, the European Union supports the promotion of employment policies and the right to work as a part of human rights (Kaya and Yilmazer, 2019). In 1997 the Amsterdam Treaty introduced the notion of European Employment Strategy (ESS). According to Article 2 of the Treaty "the Community shall include the promotion of coordination between employment policies of the Member States with a view to enhancing their effectiveness by developing a coordinated strategy for employment and Member States" and "the Community shall, in accordance with this Title, work towards developing a coordinated strategy for employment and particularly for promoting a skilled, trained and adaptable workforce and labor markets responsive to economic change" (Article 109n). In 2000, the Lisbon European Council updated the ESS and committed to create conditions for full employment and strong cohesion. According to Article 2D of Lisbon Treaty "the Union shall take measures to ensure coordination of the employment policies of the Member States, in particular by defining guidelines for these policies". The ESS coordinates employment policies in the EU level setting objectives, targets and priorities concerning employment policies and the national governments have the responsibility to plan and implement the labor policies. A substantial element of ESS is the development of Active Labor Market Policies that include measures as job search, vocational training, assistance, job creation and wage allowances to the private sector (Casey, 2004; Watt, 2004). Many countries in the European Union are using these labor policies for the last years. When developing a portfolio of active labor policies, the decision-makers have to focus on the type of program and the target groups. Incentive schemes for the private sector should be fostered and training programs should be continued (Nehme and Nehme, 2016). In the European strategy for labor policies, considerable role also plays the contribution of social partners and social dialogue (apropos Casey, 2004; Koutroukis and Kretsos, 2008). Active Labor Policies in European Countries 
include (Carcillo and Grubb, 2006; Kluve and Card, 2007; Immervoll and Scarpetta, 2012; Galata and Chrysakis, 2016): (1) Training programs; (2) Private sector incentive schemes; (3) Direct employment programs, in the public sector; (4) Services and Sanctions; (5) Youth programs and (6) Measures for the disabled.

\subsection{Labor policies and measures adopted in Greece during Covid-19}

Covid-19 has changed the work landscape. From March 2020 onwards, lockdown and mandatory closure or suspension of operation of businesses led to new legislative acts regulating measures for employees and labor relations institutions. The measures include teleworking, suspension of employment contracts, "Sinergasia" mechanism, special care for vulnerable and disadvantaged employees, special purpose leave for vulnerable employees and parents, allowances for employees, scientists and self-employed, training programs and extension of unemployment benefits (Bakirtzi, 2020).

Suspension of employment contracts: There are cases in which the employment relationship is suspended, and although no work is provided by the employee, the employment relationship is maintained to continue when the grounds for suspension have expired. The time of suspension is considered a time of employment for all the rights of the employee. The suspension of the employment relationship occurs either by a relevant agreement of the two parties (contractual suspension), or by a rule of law (suspension by law). The suspension of employment relation results in all or part of the termination of the mutual obligations of the employee and the employer for the provision of work and payment of wages, or the termination only of the obligation to provide employment without the corresponding termination or complete termination of the obligation of the employer to pay salary.

Teleworking: Teleworking is one of the most widespread forms of flexible employment and is considered as the work provided by a person for a short or long period of time outside the premises of the employer's company, and for the provision of telework, information technologies are used. Until Law 3846/2010, there was no legislation in Greece on the status of teleworking and because of this lack in the constitutional framework of teleworking, Article 4 of the National General Collective Agreement (NGCA) of 12.04.2006 defined the immediate implementation of the European Collective Agreement - framework for teleworking. In general, according to the European Agreement: Teleworking is voluntary, and it is chosen by employees on a voluntary basis, teleworkers enjoy the same rights guaranteed by the labor law and collective agreements with employees working within the company's premises, teleworker has the right to determine the organization 
of his working time within the framework of the applicable legislation, collective agreements and business regulations, the personal data of the teleworker are protected, the privacy, health and occupational safety of the teleworker are protected and teleworkers have the same collective rights as the employees on the company's premises.

Law 3846/2010 established for the first-time rules in order to specify the general obligations for teleworking. According to this law, the employer is obliged to inform the employee - teleworker about all the information related to the execution of the work and specifically about the hierarchical connection with his superiors, its detailed duties, the way of remuneration, the way of measuring the working time and the restoration of the costs caused by its provision such as equipment, telecommunications, equipment failures $(5 \S$ 1 Law 3846/2010). Also, the employer bears the responsibility and the cost of providing technical support, installation, maintenance, and operation of the required equipment and especially telecommunications $\left(\begin{array}{llll}5 & \S & 3 & \text { Law }\end{array}\right.$ $3846 / 2010$ ). At the same time, the employer is obliged to inform the teleworker about the person and the contact details of the employee representatives in the company. In this way, teleworkers are guaranteed the same collective rights that other employees of the company have ( 5 § Law $3846 / 2010)$.

Shift employment: Shift employment (Law 2639/1998; 3846/2010; $3899 / 2010$ ) is considered to be full-time employment with fewer days per week or fewer weeks per month or fewer months per year or a combination of them. The system of shift employment is an exceptional law, introducing a deviation from the fundamental rights of employees, as it can be imposed unilaterally by the employer either on all or part of the staff of the company. The imposition of shift employment due to a reduction in the economic activity of the company is a substitute for the termination of the employment contract as it could be imposed as a precautionary measure against redundancies. The legal implementation of shift employment requires the assistance of substantive and formal conditions: Essential conditions: (1) Restriction of business activity for any reason such as due to the pandemic; (2) Time limits. The duration of the shift employment is not allowed if it exceeds nine months in the same calendar year; (3) Non-abusive exercise of the right. Formal requirements: (1) Written form of shift employment; (2) Prior information and consultation with the legal representatives of the employees; (3) Notification to the Hellenic Labor Inspectorate. When the above conditions are met, the shift employment system is legally applied. In this case, there is a reduction in working time and a corresponding reduction in the employee's salary for the critical period. The principle of equality and 
the principle of non-discrimination of shift employees towards full-time employees must be respected when enforcing the system of shift employment.

The "Sin-ergasia" mechanism: The Joint Ministerial Decision of the Ministers of Finance and Labor and Social Affairs 23103/478 (14-6-2020) defined the framework for the implementation of the employment support mechanism "Sin-Ergasia". The purpose of this mechanism is to support employment. The mechanism was applied from June 15 to 15 October 2020, and for some companies, until 31 December 2020. All companies with at least $20 \%$ reduction in business turnover have the right to join the mechanism. The program concerns only full-time employees. As long as the contract of an employee is part of the mechanism, the nominal salary cannot be changed. It is possible to reduce the working hours of employees up to $50 \%$ with a corresponding reduction in salary. For the time the employee is not working, the state will pay $60 \%$ of the salary and insurance contributions corresponding to this period. The final amount that the employee will receive cannot be lower than the minimum wage. Only the specific employees whose contracts have been included in the mechanism are prohibited from being dismissed. The "Sin-ergasia" mechanism is a way for the employer to manage the reduction of business turnover, without having to lay off employees. The financial burden is distributed as follows. The employee will see a reduction of salary up to $20 \%$, if his working hours are reduced to the maximum possible of $50 \%$.

The state bears the obligation to cover $60 \%$ of the losses, just to keep the salary reduction at tolerable levels. The employer continues to be obliged to cover the remaining salary and insurance contributions and, however, cannot reduce the employee's working hours by more than $50 \%$.

Policies for vulnerable groups, parents and self-employed: For the vulnerable groups of employees' special-purpose leave is introduced and measures as back-office work and no contacts and transactions with the public. Greece is among the countries that introduced special paid leave for working parents who cared their minor children at home during school lockdowns. The special-purpose leave is a special three-day leave scheme followed by the grant of one day of regular annual leave and is cyclically repeated every four days as long as employees are entitled to annual leave. More specifically, the first two days are granted with remuneration by the employer, the third day is subsidized by the regular budget and the fourth day is deducted from the employee's annual regular leave. Employees with suspended employment contracts, freelancers, employees within the culture section and within the tourism sector, scientists, self-employed and traders affected due to the pandemic are given allowances and financial assistance. There is also an extension of unemployment benefits duration and an attempt to extend the 
Greek public works programs "Koinofelis Ergasia" (Bulman, 2020). Several attempts are also made to create training programs for the young unemployed.

\subsection{Measures introduced by OECD countries in response to COVID-19}

Among the measures introduced by OECD countries to address the coronavirus crises are the minimization of employees' exposure to Covid-19 in the workplace, the protection of employees from COVID-19 helping them with unforeseen family care needs, the provision of paid leave to sick or quarantined workers, the help to employees with additional family care needs, the securement of jobs and maintaining essential service provision, the provision of liquidity relief for firms, the limit to economic dismissals protecting employees against unfair dismissal, the provision of income security and employment support to affected workers, the provision of income support for those losing their job or their self-employment income, the creation of employment services and training for job seekers and employees (OECD, 2020b).

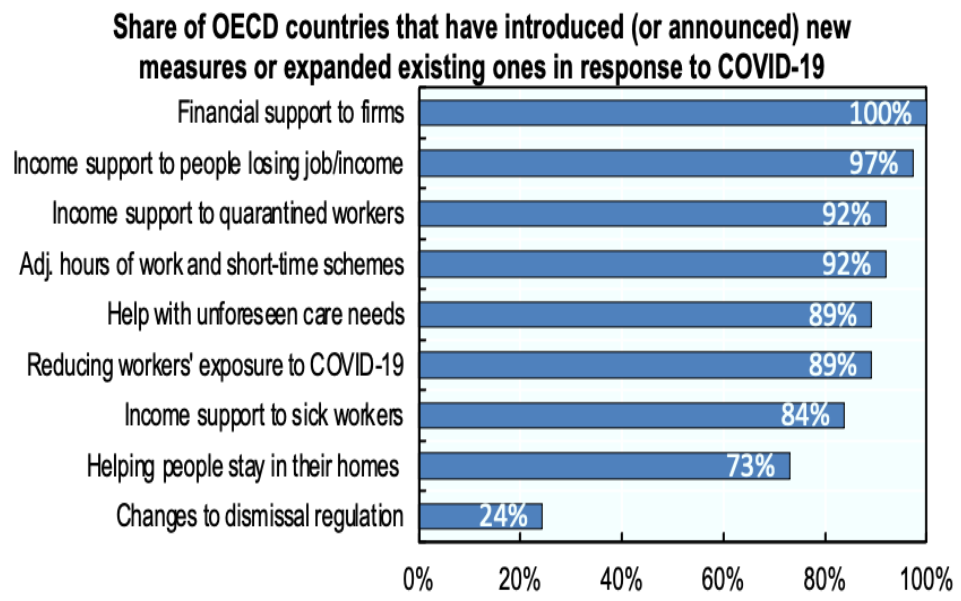

Source: OECD (2020a), 'Supporting people and companies to deal with the Covid-19 virus: Options for an immediate employement and social-policy response", ELS Policy Brief on the Policy Response to the Covid-19 Crisis, OECD, Paris, http://oe.cd/covid19tablesocial

\section{Conclusion}

This study is an attempt to explore the impact of Covid-19 on labor relations and public labor relations policies. Focus is given to the worldwide effects of the pandemic on employment, the impact of Covid-19 in the European labor landscape, the impact of the pandemic in the Greek labor context, and the main labor policies and measures adopted in Greece during Covid-19. 
The European stakeholders have declared a strong will to continue a tripartite concertation during the post-Covid-19 period. Thus, International Labor Office has recommended that policymakers should implement recovery strategies based on social partnership schemes and foster proper reforms in order to build a more sustainable, inclusive and/or resilient labor market landscape (ILO, 2021). Due to the urgent circumstances, the main labor market measures against the Covid-19 pandemic in Greece, were planned and implemented by the Ministry of Health, a governmental department that has not adopted the tripartite concertation. On the other hand, the role of the Ministry of Labor was limited. Thus, inions and other forms of labor representation were ignored or put aside.

Policies need to maintain public and private investments and infrastructures promoting job creation, manage the return to the economic and social activities keeping the employees safe, adapt support programs for the self-employed and small businesses, supporting job creation and assisting job seekers and young people with public and private employment services and active labor market measures as counseling, job search assistance, entrepreneurship programs. Special provisions and policies are necessary for the elderly, women, people with disabilities and low-income earners and the young generation of employees. Essential role in strengthening the labor market resilience play social dialogue and collective bargaining. Social partners working in collaboration could adapt the required responses to the Covid-19 pandemic through ad hoc arrangements that suit specific circumstances. Social dialogue, trade unions, works councils and other forms of employee representations are crucial in ensuring safety in the workplace, reorganization and restructuring. Generally, policies, measures, and decisions should not leave anyone behind.

Thus, the fundamental stakes in contemporary sanitary circumstances are: i) to protect employees' health and safety; ii) to promote skill upgrading with an emphasis on green and digital skills; iii) to face the psychological impact of quarantine; iv) to guarantee workers' income during the lockdowns; v) to ensure the implementation of labor law and/or collective agreements.

Planning and implementing active and effective labor policies is a demanding goal that requires the cooperation of many stakeholders and synergies among economic, research, innovation and lifelong education policies.

\section{References:}

1. Bakirtzi, E. (2020). COVID-19 and Labour Law: Greece. Italian Labour Law e-Journal, 13(1S), 1-4.

2. Brodeur, A., Gray, D., Islam, A., \& Bhuiyan, S. (2020). A literature review of the economics of COVID-19. Journal of Economic Surveys, $1-38$. 
3. Bulman, T. (2020), "Rejuvenating Greece's labour market to generate more and higher-quality jobs", OECD Economics Department Working Papers, No. 1622, OECD Publishing, Paris, https://doi.org/10.1787/8ea5033a-en

4. Carcillo, S., \& Grubb,D. (2006), "From Inactivity to Work: The Role of Active Labour Market Policies", OECD Social, Employment and Migration Working Papers, No. 36, OECD Publishing, Paris, June, www.oecd.org/els/workingpapers

5. Casey, B. H. (2004). The OECD jobs strategy and the European Employment Strategy: Two views of the labour market and the welfare state. European Journal of Industrial Relations, 10(3), 329-352.

6. Chatzinikolaou, D., Demertzis, M., \& Vlados, C. (2021). European Entrepreneurship Reinforcement Policies in Macro, Meso, and Micro Terms for the Post-COVID-19 Era. Review of European Studies, 13(2), 39-56.

7. Eurofound (2020). Living, working and COVID-19, COVID-19 series, Publications Office of the European Union, Luxembourg.

8. Ergani (2019). Hellenic Ministry of Labour and Social Security. Data from Information System "Ergani" (December 2019).

9. Ergani (2020). Hellenic Ministry of Labour and Social Security. Data from Information System "Ergani" (December 2020).

10. Galata, P. V., \& Chrysakis, M. (2016). Active Labour Market Policies in Greece: Challenges and responses during the economic crisis. Social

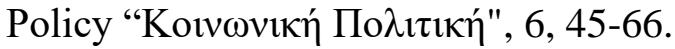

11. Fana, M., Tolan, S., Torrejón, S., Urzi Brancati, C., and FernándezMacías, E. (2020). The COVID confinement measures and EU labour markets, EUR 30190 EN, Publications Office of the European Union, Luxembourg, ISBN 978-92-79-18812-4 doi:10.2760/079230, JRC120578.

12. Hazakis, K. J. (2021). Is there a way out of the crisis? Macroeconomic challenges for Greece after the Covid-19 pandemic. European Politics and Society, 1-15.

13. ILO (2021). A global trend analysis of the role of trade unions in times of Covid-19: A summary of key findings (executive summary), Geneva, International Labour Organisation.

14. ILO Monitor: COVID-19 and the world of work. Seventh edition (2021).

https://www.ilo.org/wcmsp5/groups/public/@dgreports/@dcomm/do cuments/briefingnote/wcms_767028.pdf

15. Immervoll, H., \& Scarpetta, S. (2012). Activation and employment support policies in OECD countries. An overview of current approaches. IZA Journal of Labor Policy, 1(1), 1-20. 
16. Kaya, P. A., \& Yilmazer, I. U. E. (2019). The Right to Work as a Fundemantal Human Right. European Scientific Journal, ESJ, 15(14), 151-174.

17. Koutroukis, T., \& Kretsos, L. (2008). Social dialogue in areas and times of depression: Evidence from regional Greece. African Journal of Business Management, 2(4), 077-084.

18. Kluve, J., \& Card, D. (Eds.). (2007). Active labor market policies in Europe: Performance and perspectives. Berlin:Springer Verlag

19. Maris, G. (2021). Introduction: Eurozone and the Greek economic crisis in 2020: current challenges and prospects. European Politics and Society, 1-4.

20. Nehme, E., \& Nehme, G. (2016). Labor Market And Professional Integration Of Youth In Lebanon: Why Employment Fails?. European Scientific Journal, ESJ, 12(10), 366-386.

21. OECD, (2020a). "Supporting people and companies to deal with the Covid-19 virus: Options for an immediate employement and socialpolicy response", ELS Policy Brief on the Policy Response to the Covid-19 Crisis, OECD, Paris, http://oe.cd/covid19briefsocial.

22. OECD, (2020b). OECD Employment Outlook 2020: Worker Security and the COVID-19 Crisis, OECD Publishing, Paris, https://doi.org/10.1787/1686c758-en.

23. Plimakis, S., Maris, G., Masouras, A., Galanos, G., \& Karachalios, G. (2021). EU Structural funds and employment policy performance in Greece: impact and reform during the fiscal austerity years. European Politics and Society, 1-15.

24. Spyridakis, M. (2020). Covid-19: Full teleworking in Greece. Urbanities, 10, (4), 56-60.

25. Vlados, Ch. (2020a). Development and underdevelopment from the perspective of evolutionary socioeconomics in the post-COVID-19 era. Journal of Economic and Social Thought, 7(4), 181-212.

26. Vlados, Ch. (2020b). The growth and development analytical controversies in economic science: A reassessment for the post-Covid19 era. Journal of Economics and Political Economy, 7(4), 209-233.

27. Watt, A. (2004). Reform of the European employment strategy after five years: A change of course or merely of presentation? European Journal of Industrial Relations, 10(2), 117-137. 